\title{
Field Activity of Reticulitermes grassei (Isoptera: Rhinotermitidae) in Oak Forests of the Southern Iberian Peninsula
}

by

Ana M. Cárdenas ${ }^{1^{*}}$, Lourdes Moyano ${ }^{2}$, Patricia Gallardo ${ }^{3} \&$ Juan M. Hidalgo ${ }^{4}$

\begin{abstract}
This paper presents preliminary data on the field activity of Reticulitermes grassei Clément in oak forests of the southern Iberian Peninsula. Recent research has provided information on the nature and intensity of termite damage to cork oaks (Quercus suber, L.) in northern Andalusia (Spain). Taking that information into account, the present study sought to determine annual field activity pattern in $R$. grassei, with a view to identifying more precisely the best time for applying control techniques. Data were obtained from field monitoring experiments conducted over a complete one-year cycle using termite-specific baited traps. Results for relative termite numbers at different periods indicated that forest activity was most intense in mid-summer, whilst the surface foraging area was greatest from late summer to early fall, peaking after the first autumnal rains. The findings of this study may help to enhance the efficacy of termite bait treatments in natural environments, since baits decay and lose effectiveness over time, and are also dispersed by the termites themselves. Accurate information on peak termite activity periods would enable products to be applied in most favorable timing, thus optimizing the results of treatment.

Keywords: Field activity, Iberian Peninsula, Quercus suber, Reticulitermes grassei, Rhinotermitidae

\footnotetext{
${ }^{1}$ Department of Zoology. Campus Rabanales. University of Córdoba. E-17071. Córdoba (Spain). E-mail:balcataa@uco.es

${ }^{2}$ Department of Zoology. Campus Rabanales. University of Córdoba. E-17071. Córdoba (Spain). E-mail:b22moayl@uco.es

${ }^{3}$ Departament of Zoology. Campus Rabanales. University of Córdoba. E-17071. Córdoba (Spain). E-mail: b42gatop@uco.e

${ }^{4}$ Departament of Zoology. Campus Rabanales. University of Córdoba. E-17071. Córdoba (Spain). E-mail: zo2himaj@uco.ess
} 


\section{INTRODUCTION}

Termites are social insects that cause major damage to wooden structures in urban environments, but they also form part of natural ecosystems (Haverty \& Sunden-Bylehn 2000), where their most obvious role is in decomposition and in determining specific pathways for the subsequent humification and mineralization of residual materials (Bignell \& Eggleton 2000).

Given the particularly cryptic behavior of termites, they tend to go unnoticed until the damage they cause has become highly manifest and their foraging territories are widespread. Following Eggleton (2000) and Lenz et al. (2003), termites are generally classified by habits and habitats as follows:

Damp wood termites: inhabit and eat damp wood, especially stumps and fallen trees on the forest floor.

Dry wood termites: require no contact with the ground, live in trees, usually in the treetops, and tolerate low environmental humidity.

Subterranean termites: numerous in many parts of the world, living and reproducing in soil and feeding mainly on wood. Some subterranean termites can build epigeal nests, and are major pests in towns and cities.

Mushroom growers: these termite species collect grass, leaves or wood, which are processed by Basidiomycetes 'symbionts' grown in chambers inside the termites' mound. Through specific enzymes, fungi 'digest' plant debris taken by termites into the mound.

Four termite species are known in the Iberian Peninsula: two subterranean species (Reticulitermes grassei Clément and R. banyulensis Clément), and two dry-wood species: Kalotermes flavicollis (Fabricius) and Cryptotermes brevis (Walker). Of these, only R. grassei and K. flavicollis are found in Andalusia, occurring both in natural environments and in urban areas, where they are responsible for extensive damage and significant economic losses.

$R$. grassei colonies have been reported in most of the Iberian Peninsula, with the exception of a small north-eastern area (between Catalonia, Navarre and the Ebro river basin) which is occupied by $R$. banyulensis.

Like other Reticulitermes species, $R$. grassei usually eats the dead wood of old or senescent trees, and also attacks rural dwellings and urban structures such as buildings, bridges and dams. Research has found that the termite is 
a major pest in certain areas of Andalusia, including Palenciana (Córdoba), where it has been recorded in over 33\% of homes (Gaju et al. 2002). Although termites are also very common in most Iberian forests, the presence of $R$. gras$s e i$ has not so far been classed a pest problem in natural ecosystems. Recently, however, our research group discovered a new type of damage affecting cork oaks (Quercus suber L.) in southern Iberian forests. The termite $R$. grassei was identified as the cause of sinuous galleries and adhesions that were hampering cork extraction, thus prompting economic losses (Gallardo et al. 2010). Numerous papers address termite biology, focussing on the number of instars, the definition of workers and the terminology used to differentiate castes. An overview of the literature on the life cycle of Reticulitermes spp. can be found in Lainé et al. (2003). However, no data are available on the field activity of this species in natural environments. Most observations of foraging behavior and ecology in subterranean termites have been conducted in tropical forest environments (Bignell \& Eggleton 2000).

The pest management of subterranean termites is a complex issue: for many years, they were controlled by chemical barriers, which involved the abundant use of insecticides despite considerable toxicity both for humans and for the environment. Newer, alternative termite-control methods require the placing of baits containing specific low-toxicity substances (usually chitin-synthesis inhibitors, Verker \& Bravery 2000; 2004).

Successful control of $R$. grassei using baiting systems has been reported in urban areas of Andalusia (Alcaide 2010): termites feed on a lethal bait placed in a monitoring station, and thereafter spread the bait inside the mound, transferring it - through their trophallaxic behavior - to other members of the colony. Clearly, control and treatment measures are most effective during periods of increased foraging and feeding activity, since more individuals are affected and the amount of insecticide ingested is higher.

Given its specificity and mode of application, this method might also be suitable for pest control in forest environments. Nevertheless, attention should be paid to the environmental variables influencing the distribution, density and seasonal activity of subterranean termites (Haagsma 1995; Ramirez \& Lanfranco 2001); in temperate areas, fluctuations in temperature and humidity are more manifest in forest environments than in urban constructions. The 
present study therefore sought to examine $R$. grassei field activity patterns in order to identify periods of peak activity, thus enabling the optimal timing of any control treatment required.

\section{MATERIALS AND METHODS}

\section{Sampling area}

To study $R$. grassei field activity patterns, a pure cork-oak stand was selected, where termite damage (affecting $68.63 \%$ of trees) had previouslybeen detected. The plot is located in central Sierra Morena (southern Iberian Peninsula), belongs to the "Los Baldíos" farm (UTM coordinates 30 S 0335094- 4200826) and is part of the Recovery Management Program linked to the construction of the Breña II dam (Cárdenas et al. 2008).

According to Gallardo et al. (2010), the research area is of great ecological value, and comprises a gallery forest growing on the banks of the Bejarano stream (a tributary of the River Guadiato), and a mixed-oak forest dominated by Quercus ilex L., Q. suber L. and Q. faginea Lam., predominate, but also containing other tree species including Pinuspinea L. and Olea europaea var. sylvestris Brot. The most representative scrubland species are Genista spp., Cistus salvifolius L. and Daphne gnidium L.

Local soils are predominantly acid, and the climate is typically Mediterranean. Bioclimatologically, the area lies between the thermo-Mediterranean and meso-Mediterranean belts, with broad transitional zones (Cárdenas \& Bach 1989).

Climate data (monthly average temperature and rainfall) recorded at the Trassierra weather station (closest to the study area) during the sampling period (http://www.aemet.es 2011) are shown in Fig. 1.

\section{Field sampling}

Field sampling was carried out from November 2009 to October 2010, using termite-specific baited traps. A survey of the different methods used for sampling for subterranean termites can be found in Bignell \& Eggleton (2000). On the basis of this information, a sampling procedure similar to that used in earlier research (Gallardo et al. 2010) was used, placing a set of baited traps at the foot of damaged trees. 
Forty trees were randomly selected in an area where termite damage had previously been observed. Trees were marked (Fig. 2) and geo-referenced (Table 1). The average distance between sampled trees was $12.36 \mathrm{~m} \pm 4.46$ $\mathrm{SD}$, and tree density for the study areas as a whole was 37 trees/ha.

A total of 40 baited traps were placed in the study plot (one at the foot of each selected tree). Each trap consisted of a container measuring $20 \mathrm{~cm}$ in diameter and $15 \mathrm{~cm}$ in height, open at the base and containing an untreated block of wood of roughly $10 \times 5 \times 5 \mathrm{~cm}$ that acted as starting bait. The trap also contained additional bait in the form of a pack of several previously-moistened strips of corrugated cardboard $(25 \times 5 \times 0.5 \mathrm{~cm})$. The trap was covered with a lid and was buried about $20 \mathrm{~cm}$ deep in the soil at the base of each tree; a little soil and straw were added. After around 35 days, the additional bait was removed and replaced. Once in the laboratory, the corrugated cardboard strips were minutely examined to check for termites. Workers and soldiers were isolated, identified and counted. A total of 10 samplings were performed over the total sampling period (Table 2).

SPSS and AUTOCAD programs were used for statistical analysis and graphic plotting, respectively.

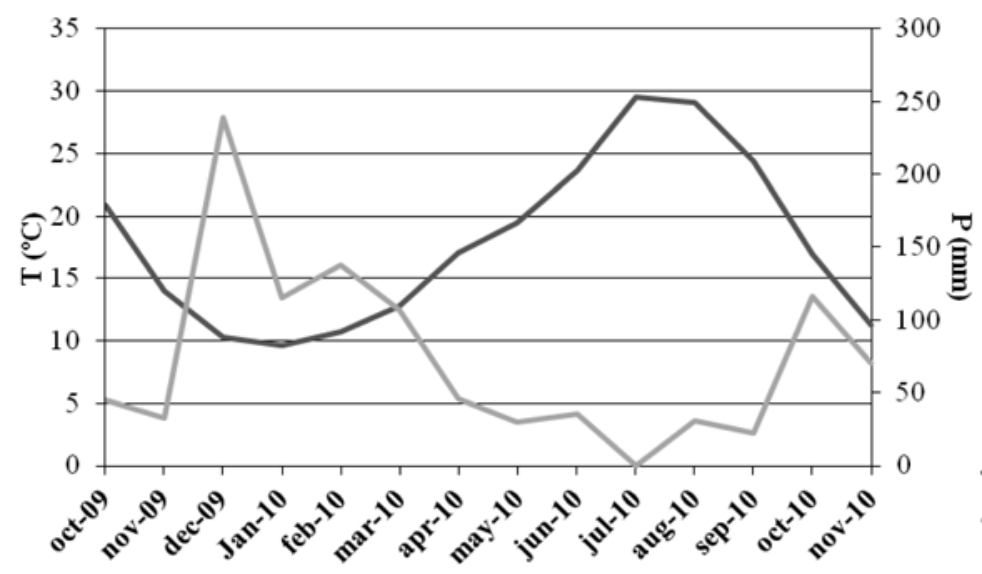

Fig.1. Monthly data of average Temperature $\left({ }^{\circ} \mathrm{C}\right)$ and Precipitation $(\mathrm{mm})$ recorded at the meteorological station of Trassierra (closest to the study area) during the sampling period. 


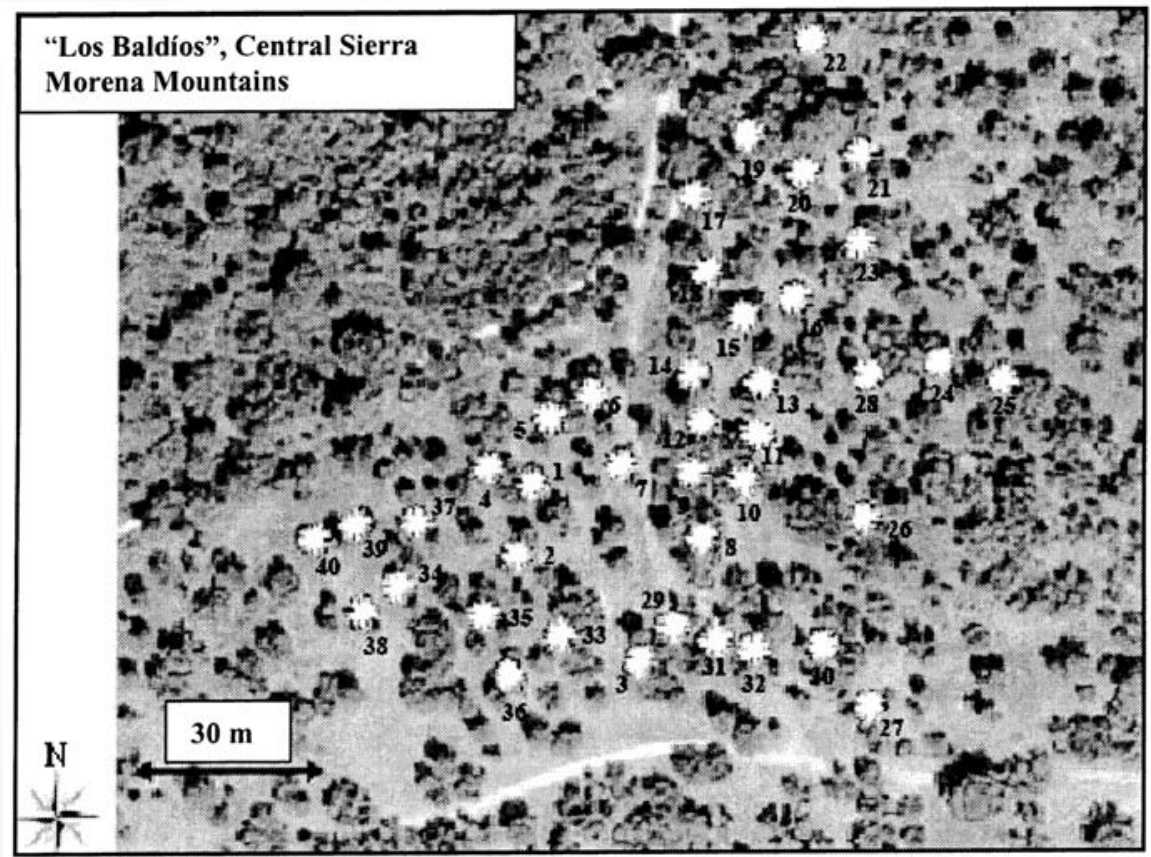

Fig. 2. General overview of the sampling area showing the sampled cork oaks (white colored and numbered trees).

\section{RESULTS}

Reticulitermes grassei field activity was analyzed in terms of changes in activity patterns and changes in the area of surface activity over time. These two parameters were considered independently of each other, on the basis of the sampling data recorded in Table 3.

\section{Field activity patterns}

To chart changes in $R$. grassei numbers over time, an analysis was made of monthly data for total termite numbers, and also for numbers of workers and soldiers captured during the sampling period. Results are plotted in Fig. 3.

The graph clearly shows an extended period of peak surface activity. Termite activity started in May and gradually increased, peaking in July and August, thereafter declining from late summer through fall, and reaching minimal values in winter due to extreme climate conditions. Nevertheless, some workers were still observed in winter. 
Table1. UTM Coordinates and tree reference (ref.) for the sampled cork oaks.

\begin{tabular}{|c|c|c|c|c|c|c|c|}
\hline $\begin{array}{l}\text { Tree } \\
\text { (ref.) }\end{array}$ & $\begin{array}{l}\text { UTM } \\
\text { coordinates }\end{array}$ & $\begin{array}{l}\text { Tree } \\
\text { (ref.) }\end{array}$ & $\begin{array}{l}\text { UTM } \\
\text { coordinates }\end{array}$ & $\begin{array}{l}\text { Tree } \\
\text { (ref.) }\end{array}$ & $\begin{array}{l}\text { UTM } \\
\text { coordinates }\end{array}$ & $\begin{array}{l}\text { Tree } \\
\text { (ref.) }\end{array}$ & $\begin{array}{l}\text { UTM } \\
\text { coordinates }\end{array}$ \\
\hline 1 & $\begin{array}{l}0335498 \\
4201512\end{array}$ & 11 & $\begin{array}{l}0335558 \\
4201495\end{array}$ & 21 & $\begin{array}{l}0335560 \\
4201577\end{array}$ & 31 & $\begin{array}{l}0335547 \\
4201462\end{array}$ \\
\hline 2 & $\begin{array}{l}0335509 \\
4201466\end{array}$ & 12 & $\begin{array}{l}0335536 \\
4201485\end{array}$ & 22 & $\begin{array}{l}0335568 \\
4201577\end{array}$ & 32 & $\begin{array}{l}0335552 \\
4201464\end{array}$ \\
\hline 3 & $\begin{array}{l}0335511 \\
4201459\end{array}$ & 13 & $\begin{array}{l}0335563 \\
4201519\end{array}$ & 23 & $\begin{array}{l}0335580 \\
4201548\end{array}$ & 33 & $\begin{array}{l}0335501 \\
4201467\end{array}$ \\
\hline 4 & $\begin{array}{l}0335494 \\
4201504\end{array}$ & 14 & $\begin{array}{l}0335541 \\
4201522\end{array}$ & 24 & $\begin{array}{l}0335589 \\
4201541\end{array}$ & 34 & $\begin{array}{l}0335441 \\
4201456\end{array}$ \\
\hline 5 & $\begin{array}{l}0335499 \\
4201522\end{array}$ & 15 & $\begin{array}{l}0335543 \\
4201542\end{array}$ & 25 & $\begin{array}{l}0335593 \\
4201540\end{array}$ & 35 & $\begin{array}{l}0335491 \\
4201467\end{array}$ \\
\hline 6 & $\begin{array}{l}0335540 \\
4201549\end{array}$ & 16 & $\begin{array}{l}0335546 \\
4201543\end{array}$ & 26 & $\begin{array}{l}0335571 \\
4201477\end{array}$ & 36 & $\begin{array}{l}0335483 \\
4201437\end{array}$ \\
\hline 7 & $\begin{array}{l}0335531 \\
4201526\end{array}$ & 17 & $\begin{array}{l}0335546 \\
4201561\end{array}$ & 27 & $\begin{array}{l}0335590 \\
4201441\end{array}$ & 37 & $\begin{array}{l}0335444 \\
4201478\end{array}$ \\
\hline 8 & $\begin{array}{l}0335556 \\
4201487\end{array}$ & 18 & $\begin{array}{l}0335545 \\
4201543\end{array}$ & 28 & $\begin{array}{l}0335570 \\
4201529\end{array}$ & 38 & $\begin{array}{l}0335438 \\
4201425\end{array}$ \\
\hline 9 & $\begin{array}{l}0335542 \\
4201502\end{array}$ & 19 & $\begin{array}{l}0335553 \\
4201572\end{array}$ & 29 & $\begin{array}{l}0335523 \\
4201460\end{array}$ & 39 & $\begin{array}{l}0335435 \\
4201470\end{array}$ \\
\hline 10 & $\begin{array}{l}0335566 \\
4201508\end{array}$ & 20 & $\begin{array}{l}0335554 \\
4201578\end{array}$ & 30 & $\begin{array}{l}0335581 \\
4201464\end{array}$ & 40 & $\begin{array}{l}0335425 \\
4201458\end{array}$ \\
\hline
\end{tabular}

Table 2. Sampling dates.

\begin{tabular}{llll}
\hline \hline Sampling Number & Date & Sampling Number & Date \\
\hline $\mathbf{1}$ & $06-11-2009$ & $\mathbf{6}$ & $14-06-2010$ \\
$\mathbf{2}$ & $03-12-2009$ & 7 & $08-07-2010$ \\
$\mathbf{3}$ & $03-02-2010$ & $\mathbf{8}$ & $01-08-2010$ \\
$\mathbf{4}$ & $23-03-2010$ & $\mathbf{9}$ & $06-09-2010$ \\
$\mathbf{5}$ & $18-05-2010$ & $\mathbf{1 0}$ & $10-10-2010$ \\
\hline \hline
\end{tabular}

Activity curves for soldiers and workers considered independently ran parallel to those data for total termite activity, although workers started moving earlier and peak activity was recorded sooner than in soldiers; worker activity was also considerably greater. The caste ratio (soldiers/workers) remained constant at around $1 / 20$ throughout the year.

\section{Area of surface activity}

To track changes in the area of surface activity, the size of the area in which traps contained termites was monitored throughout the sampling period. 


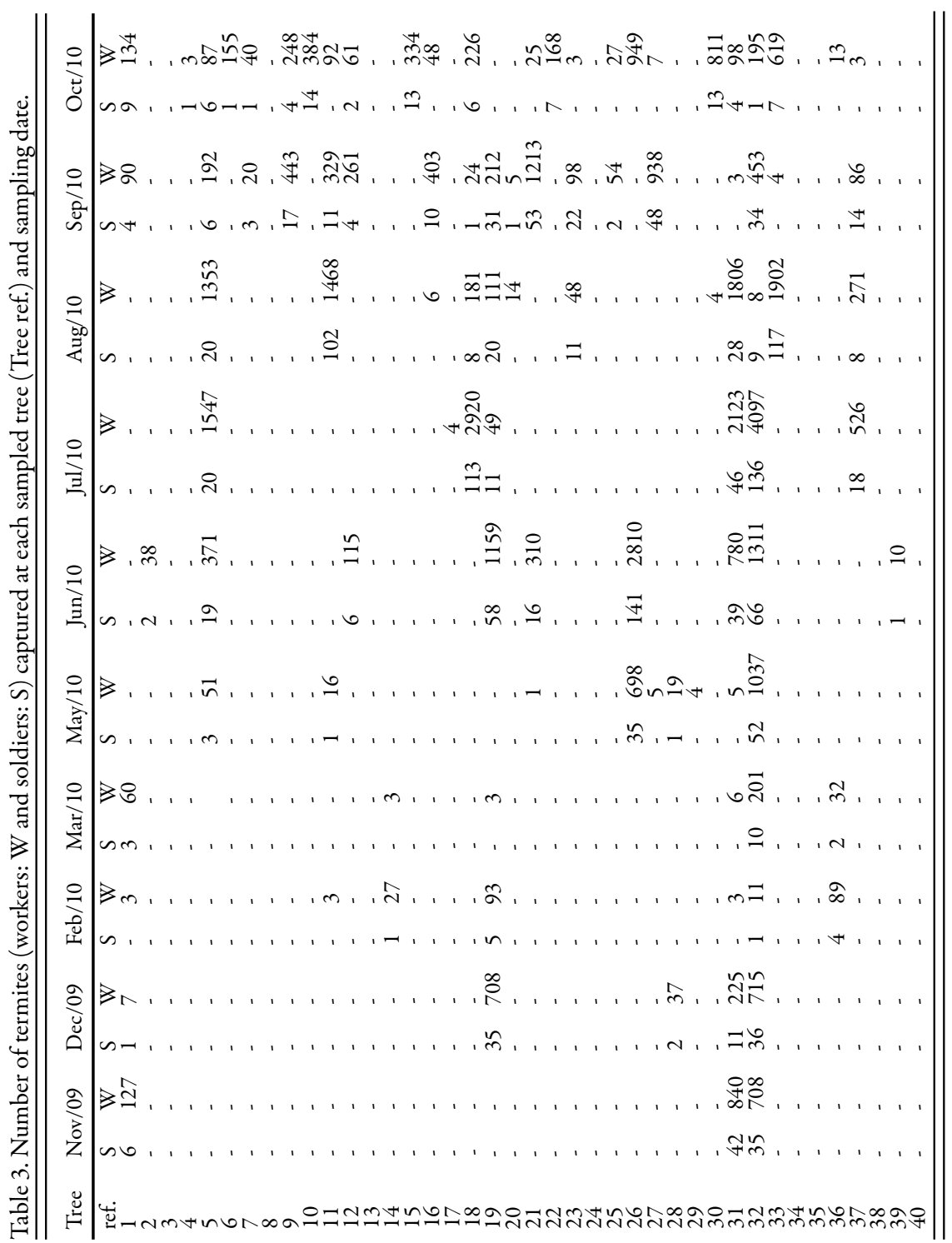


The position of sampled trees in the study area is shown in Fig. $4 \mathrm{~A}$, whilst trees with termite-containing traps are shown in Fig. 4 B, Figs. $5 \mathrm{~A}$ and B, and Figs. $6 \mathrm{~A}$ and $\mathrm{B}$.

At the start of the study (November 2009), termites were found on only three cork-oaks, but numbers progressively increased to peak at 24 trees in October 2010. Overall data from all samples (Table 3) show that termites were found at least once during the study period on 32 of the 40 trees sampled.

The scatter plot of trees colonized by termites displayed no uniform or contagious distribution: in the first sampling (November 2009), for example, only three traps contained termites but the distance between them ranged between 5 and $37 \mathrm{~m}$ (trees 1-32 and 31-32, Fig. 4 B).

The number of traps containing $R$. grassei progressively increased over time (Fig. 7), leading to an increase in the area of surface activity. Even so, the number of termite-containing traps remained below ten throughout spring and up until midsummer. From July onward, the area of surface activity extended to $80 \%$ of the sampled trees (Fig.6).

The presence of termites in sampled trees was highly irregular. In some trees, termites once detected remained throughout the rest of the sampling period; this was the case of traps located in trees 19, 31 and 32, in which termites were found from November onward. In other traps, termites were recorded sporadically, with only one or two captures over the entire sampling period; for example, in trees 39 and 17 termites were found only in June and July, respectively.

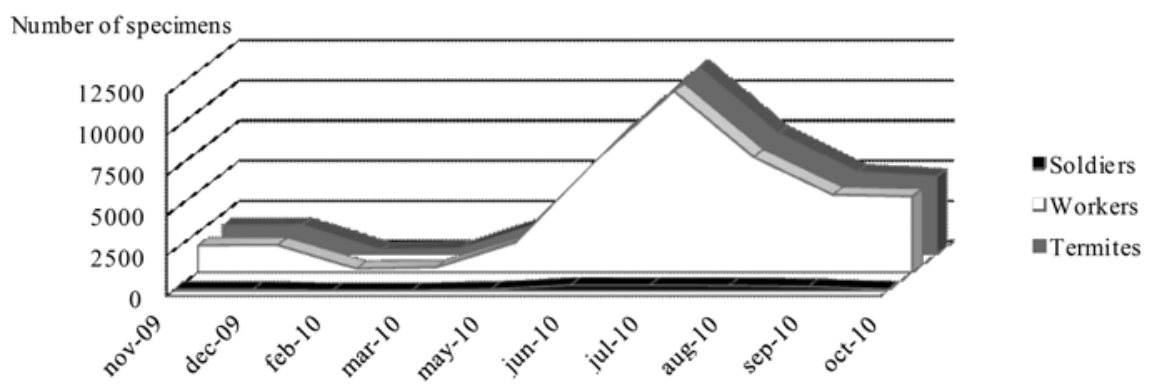

Fig. 3. Number of Soldiers, Workers and total Termites captured monthly during the sampling period. 

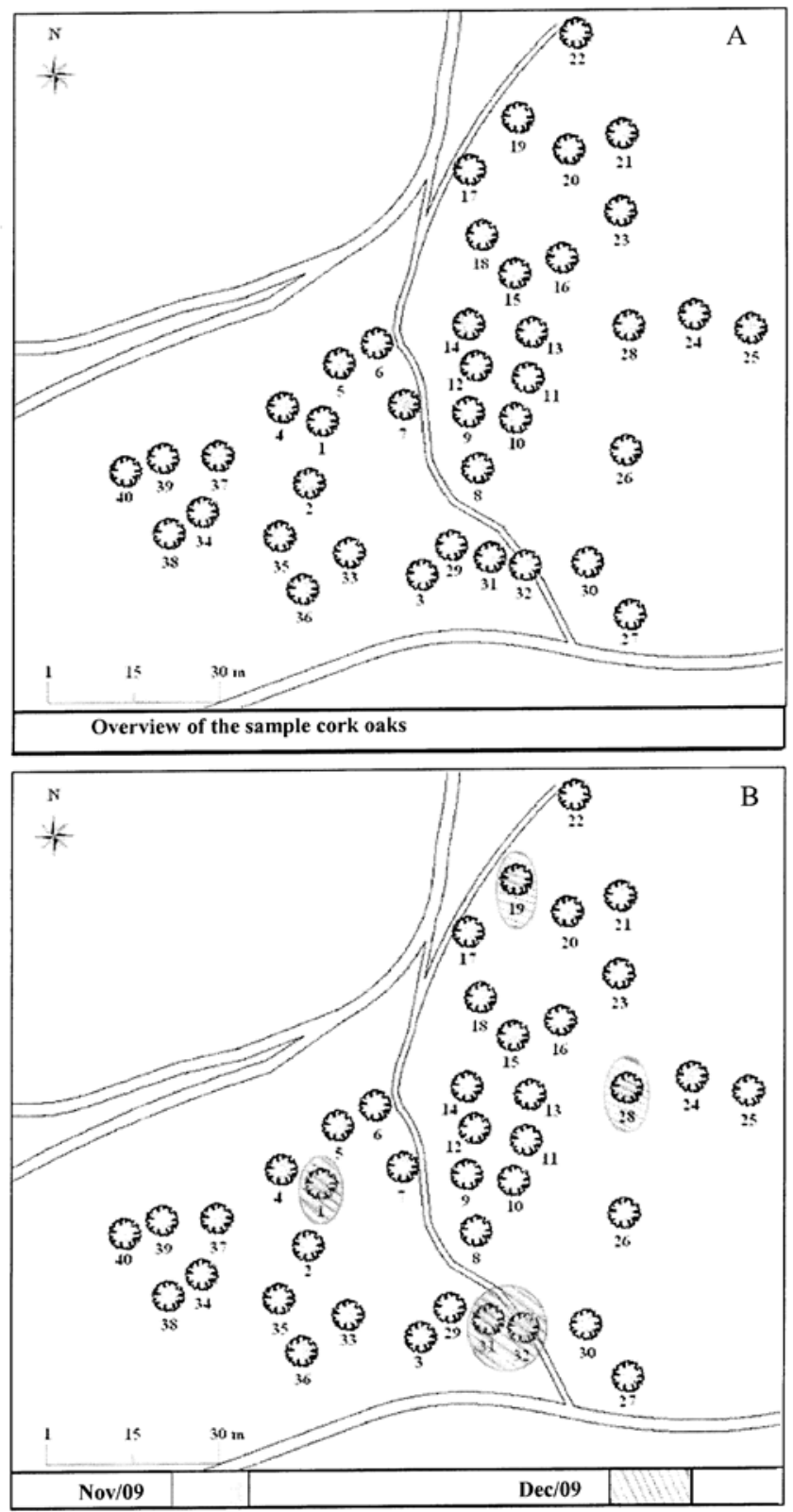

Fig. 4. A: Overview of the sampling area; symbols and numbers correspond to each sampled cork oak. B: Representation of the trees having termites in traps sampled in November - December/2009. 

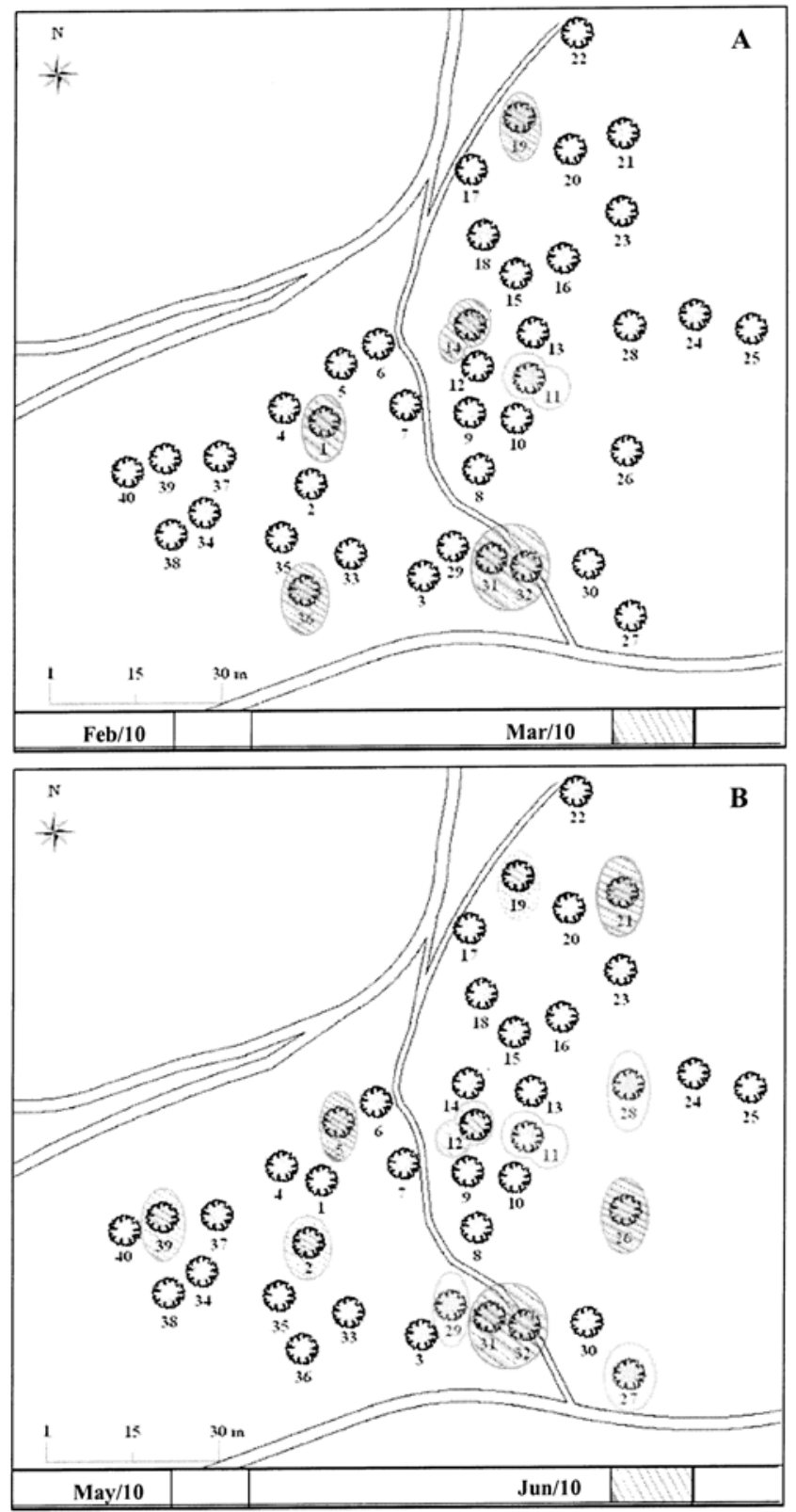

Fig. 5. Representation of the trees having termites in traps. A: FebruaryMarch/2010. B: May-June/2010. 

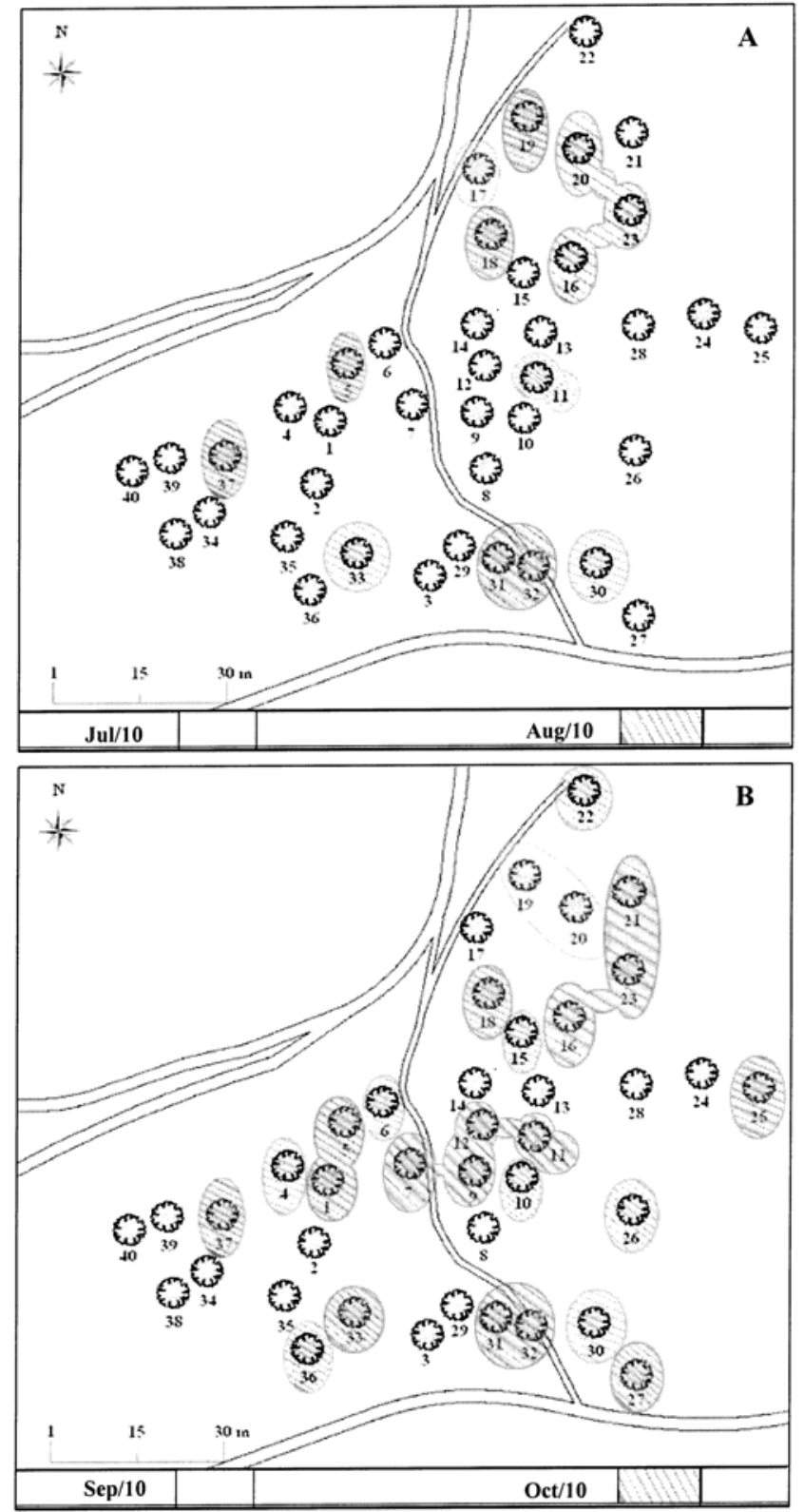

Fig. 6. Representation of the trees with termites in traps sampled. A: JulyAugust/2010. B: September-October/2010. 


\section{DISCUSSION}

Termite treatments based on the use of specific baits, including chitin inhibitors, were first applied in the mid-1990s. A number of papers have reported on the application of these products (e.g. Noviflumuron, Hexaflumuron, Diflubenzuron) for the treatment of several Reticulitermes species, including R.grassei (Getty et al.2005; Rojas et al.2008). These products have a clearance time ofbetween 2 and 34 months, depending on the concentration and the product used (Alcaide 2010). Even so, since baits decay and become less effective over time (due to desiccation, flooding....) (Eggleton \& Bignell 1995), and since they are dispersed by the termites themselves, it is essential to establish the period of greatest termite activity in order to adjust the timing of product application and thus optimize the results of treatment. This study therefore aimed to determine $R$. grassei field activity patterns in order to pinpoint periods of peak activity and identify the environmental factors most likely to influence it.

Designing a sampling protocol to estimate population size, richness or abundance for soil/wood interface feeders such as termites poses a number of challenges (Bignell \& Eggleton 2000). However, since research in this case focused not on these population parameters but on peak soil-surface activity,

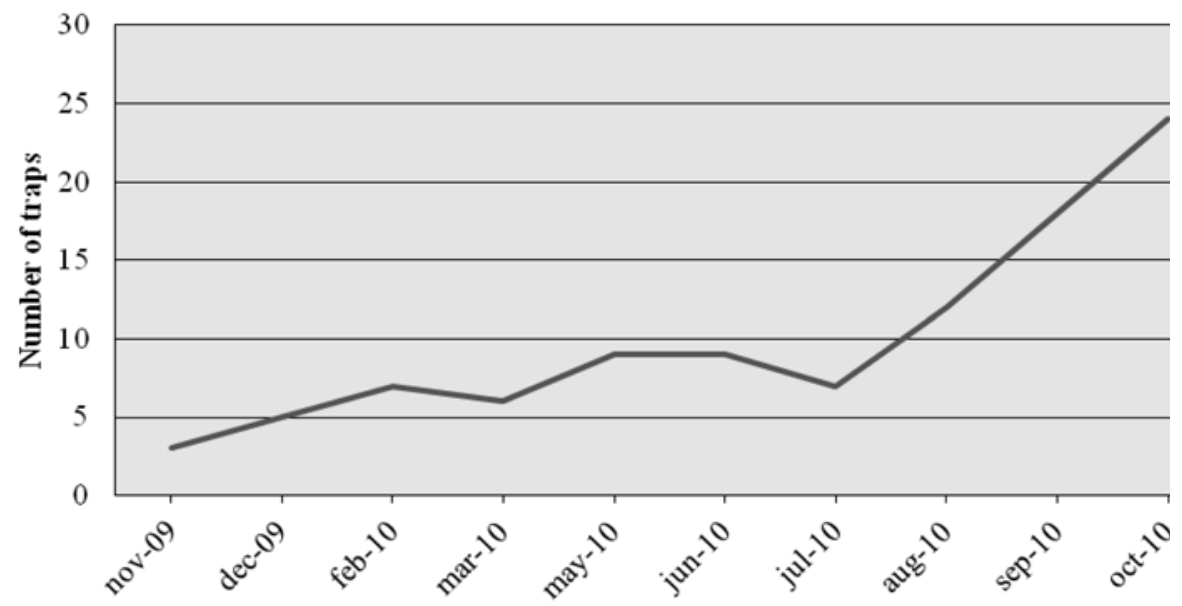

Fig. 7. Monthly number of traps containing termites. 
a field experiment was designed to monitor termite activity over a full annual cycle. The design was based on information acquired during earlier research (Gallardo et al. 2010) showing that $R$. grassei had already colonized the study area, causing damage to cork-oaks. Observations in the new study therefore concentrated on changes in termite foraging behavior, often adapted to locating new food sources (Traniello \& Leuthold 2000), rather than on dispersal or swarming strategies. Search patterns have been analyzed in two species of Reticulitermes, R. flavipes (Reinherd et al. 1997) and R. santonensis (Robson et al. 1995); mapping of foraging-gallery formation revealed a non-random search pattern, and showed that galleries were organized in such a way as to avoid overlaps. Although there are no published data on changes in search behavior over time in subterranean termites, other issues - including the division of labor among workers during foraging, and the role of pheromones in foraging behavior - have been addressed in several Reticulitermes species (Traniello \& Leuthold 2000). In the present study, most individuals involved in foraging behavior were workers; only $5 \%$ were soldiers. This is consistent with findings reported by these authors who note that, in some termite species, soldiers play an organizational and defensive role in foraging activity.

Pomeroy (1983) drew attention to the relationship between termite distribution and certain environmental variables such as rainfall mean minimum temperature and soil differences. In addition, Haagsma (1995) and Ramirez \& Lanfranco (2001) suggest that the variable most influencing the distribution, density and seasonal activity of subterranean termites is humidity (related to rainfall and temperature). Seasonality clearly affects both termite abundance and distribution (Ohiagu 1979; Wood et al. 1982; Dibog et al. 1999). Termites are generally less common in the surface layers of very dry soil, but overall population sizes may also fluctuate seasonally.

The data obtained here confirm these findings, in that the greatest area of surface activity was recorded in early October, following the first autumn rains. Peak termite numbers, however, were recorded in July, according to the thermophilous nature of this species. Even in winter, when environmental conditions would appear to be unfavorable due to low temperatures and high humidity, some individuals remained active. Lepage \& Darlington (2000) note that in seeking to maintain nest homeostasis, termite species face a number of environmental constraints: whilst other members the soil fauna, 
such as earthworms, remain quiescent during the unfavorable period (dry season), termites remain active even in periods of disturbance, in order to protect the reproductive potential of the colony and ensure recovery when conditions become favorable.

In summary, analysis of changes in population size and area of surface activity suggests that bait-based treatments for the control of $R$. grassei in southern Iberian oak forests are best applied between July and October. Nevertheless, as year-on-year variations may also occur (Bignell et al. 1997; Dibog et al. 1999), further long-term studies are required to pinpoint more accurately the optimal timing of treatment.

\section{ACKNOWLEDGMENTS}

We grateful to Ingeniería y Gestión del Sur, IPA, S.L. for the financial support, Dr. Miguel Gaju for his assistance in different aspects of this research, and Mr. José Alcántara for his assistance with the graphs.

\section{REFERENCES}

Agencia Española de Meteorología. 2011. http://www.aemet.es/es/servidor-datos/accesodatos/listado-Contenidos/detalles/series_climatologicas.

Alcaide, M.E. 2010. Estudio del control integral de una plaga urbana de termitas en el sur de España. Tesis Doctoral. Universidad de Córdoba. España. 246 pp.

Bignell, D.E. \& P. Eggleton. 2000. Termites in ecosystems. In: Abe T., D.E. Bignell \& M. Higashi (eds.), Termites: Evolution, Sociality, Symbioses, Ecology. Kluwer Academic Publisher. Dordrecht. pp 365-387.

Bignell, D.E., P. Eggleton, L. Nunes \& K.L. Thomas. 1997. Termites as mediators of carbon fluxes in tropical forest: budgets for carbon dioxide and methane emissions. In: Watt, A.D., N.E. Stork \& M.D. Hunter (eds.), Forests and Insects. Chapman and Hall. London. pp 109-133.

Cárdenas, A.M. \& C. Bach. 1989. The effect of some abiotic factors on the distribution and selection of habitat by the Carabid Beetles in the Central Sierra Morena Mountains (SW Córdoba, Spain). Vie Milieu 39(2): 93-103.

Cárdenas, A.M., E. Vargas, P. Gallardo \& S. Pérez. 2008. Medidas Compensatorias del Proyecto del Embalse de la Breña II: Estudio sobre Coleópteros Perforadores de Quercíneas. Memoria Final. Universidad de Córdoba. España.

Dibog, L., P. Eggleton, L. Norgrove, D.E. Bignell \&S. Hauser. 1999. Effects of canopy closure on abundance and assemblage composition of soil termites in an agrosilvicultural system in southern Cameron. Bulletin of Entomological Research. 89: 125-132. 
Eggleton, P. 2000. Global patterns of termite diversity. In: Abe T., D.E. Bignell \& M. Higashi (eds.), Termites: Evolution, Sociality, Symbioses, Ecology. Kluwer Academic Publisher. Dordrecht. pp 25-51.

Eggleton, P. \& D.E. Bignell. 1995. Monitoring the response of tropical insects to changes in the environment: trobles with termites. In: Harrington R. \& N.E. Stork (eds.), Insects in a Changing Environment. Academic Press. London. pp 473-497.

Gaju, M., M.J. Notario, R. Mora, E. Alcaide, T. Moreno, R. Molero \& C. Bach. 2002. Termite damage to buildings in the province of Córdoba, Spain. Sociobiology 40:75-85.

Gallardo, P., A.M. Cárdenas \& M. Gaju. 2010. Ocurrence of Reticulitermes grassei (Isoptera: Rhinotermitidae) on cork oaks in the southern Iberian Peninsula: identification, description and incidence of the damage. Sociobiology 56(3): 675-687.

Getty, G.M., C.W. Solek, R.J. Sbragia, M.I. Havertty \& V.R. Lewis. 2005. Suppression of a subterranean termite community (Isoptera: Rhinotermitidae, Reticulitermes) using a baiting system: a case study in Chatsworth, California, USA. In: Lee C.Y. \& W.H. Robinson (eds.), Proceedings of the $5^{\text {th }}$ International Conference on Urban Pest. Singapore, 10-13 July. pp 165-169.

Haagsma, K.A. 1995. Colony size estimates, foraging trends, and physiological characteristics of the western subterranean termite (Isoptera: Rhinotermitidae). Environmental Entomology 24(6): 1520-1528.

Haverty, M. \& A. Sunden-Bylehn. 2000. Finding alternatives to persistent organic pollutants (POPs) for termite management. International Activities on Persistent Organic Pollutants (POPs) covered by the Stockholm Convention. Stockholm, Sueden.

Lainé V.L., V.L. Lainé \& D.J. Wright. 2003. The life cycle of Reticulitermes spp. (Isoptera: Rhinotermitidae): what do we know?. Bulletin of Entomological Research 93(4): 267-378.

Lenz, M., A. Sunden-Bylehn, B.L. Thorne, V.R. Lewis \& M. Haverty. 2003. Finding alternatives to persistent organic pollutants (POPs) for termite management. UNEP/ FAO/Global IPM Facility Expert Group on Termite Biology and Management, United Nations Environment Programme/Food and Agriculture Organization of the United Nations/Global Integrated Pest Management Facility. United Nations Environment Programme.

Lepage, M.L. \& J.P.E.C. Darlington. 2000. Population dynamics of termites. In: Abe T., D.E. Bignell \& M. Higashi (eds.), Termites: Evolution, Sociality, Symbioses, Ecology. Kluwer Academic Publisher. Dordrecht. pp 333-361.

Ohiagu C.E. 1979. A quantitative study of seasonal foraging by grass-harveting termite Trinervitermes geminatus (Wasmann) (Isoptera: Nasutermitinae) in southern Guinea savanna. Mowa, Nigeria. Oecologia 40: 167-178.

Pomeroy D.E. 1983. Distribution and abundance of large termite mounds in a semi-arid area of southern Kenya. Kenya Journal of Science and Technology, Series B 4: 77-87.

Ramírez, C. \& D. Lanfranco. 2001. Descripción de la biología, daño y control de las termitas: especies existentes en Chile. Bosque 22(2): 77-84. 
Reinhard,J., H.Hertel \& M.Kaib. 1997. Systematic search for food in the subterraneantermite Reticulitermes santonensis De Feytaud (Isoptera, Rhinotermitidae). Insectes Sociaux 44: 147-158.

Robson, S.K., M.G.Lesniak, R.V.Kothandapani,J.F.A. Traniello, B.L. Thorne \& V. Fourcassié. 1995. Nonrandom search geometry in subterranean termites. Naturwissenschaften 82 : 526-528.

Rojas, M.G., J.A. Morales-Ramos, E. Lockwood, L. Etheridge, J.B. Carroll, M.C.H. Coker \& P.R. Knight. 2008. Areawide management of subterranean termites in south Mississippi using baits. Technical Bulletin of Agricultural Research, Service 1917: 1-44.

Traniello, J.F.A. \& R.H. Leuthold. 2000. Behavior and Ecology of Foraging in Termites. In: Abe T., D.E. Bignell \& M. Higashi (eds.), Termites: Evolution, Sociality, Symbiosis, Ecology. Kluwer Academic Publisher. The Netherlands. pp 141-168.

Verker, R.H.J. \& A.F. Bravery. 2000. The UK termite erradication Programme: justification and implementation. Doc. No. IRG/WP 00-10373.

Verker, R.H.J. \& A.F. Bravery. 2004. A case study from the UK of possible successful eradication of Reticulitermes grassei. Final Workshop COST Action E22 Environmental Optimization of Wood Protection Lisboa-Portugal, 22nd-23rd.

Wood, T.G., R.A.Johnson, S. Bacchus, M.O. Shittu \& J.M. Anderson. 1982. Abundance and distribution of termites (Isoptera) in a riparian forest in the southern Guinea Savanna near Mokwa, Nigeria. Geomorphology and Ecology of tropical and subtropical regions 1: 139-148.

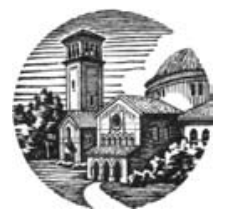


